\title{
Beowulf - The Anglo Saxon Hero
}

\section{Dr. Anupama Dogra (Ex.Asst.Prof)}

Army Institute of Higher Education, Pathankot

\author{
Alka Dogra (Asst. Prof)
}

Sri Sai College of Education, Badhani

The Anglo-Saxons were prominent in the early Middle Ages, stretching from the first century up to the Renaissance, which began around the 14th century. The Anglo-Saxons invaded what is currentday England around the year 450, and were the dominant group until the Norman invasion in 1066. The group consisted of three Germanic tribes: the Angles, the Saxons and the Jutes. However, there were many changes in society, which affected the literature. For example, the Anglo-Saxon people spoke in what is now called Old English, which is a combination of the native Briton's language and the Germanic tribal tongue they brought with them. Christianity was the religion of the Britons, and at the start of the Anglo-Saxon invasion it was suppressed. But, over the following years, these Germanic tribes converted to it. Thus, Christian ideals become popular in Anglo-Saxon literature.

The Anglo-Saxon society continued to grow over the following centuries, absorbing other cultures and rebuffing other Germanic invaders. The history of these people is reflected in the rich literature of that era. The Anglo-Saxon invaders brought with them a tradition of oral poetry, but it was Christianity that brought the written word to them. For the most part, only churchmen were literate and spent much time copying manuscripts. Thus, we see plenty of religious topics in the written works of that era.

Let's look at some of the more prominent traits of Old English poetry. One comes from the original Germanic tribes, which valued heroic poetry. It honored brave feats and specific codes of conduct. This type of poetry also emphasized strong kinship, with a generosity to not just blood relatives, but to all people in the tribe. The king must follow a code of royal generosity, rewarding his faithful followers. In addition, the king's subjects must follow a code of blood vengeance, fighting to the death for their king, and avenging him if he is slain (or any kinsman for that matter). To fail to do so is to suffer endless shame.

One Old English poem, Beowulf, has many great examples of heroic poetry. It is the story of a warrior who saves his people from evil monsters through courageous deeds. There is strong kinship between Beowulf and King Hrothgar. Beowulf must kill three monsters to avenge his men that have been killed. There is also kinship between Beowulf and his soldiers, who mourn his death and praise him for his bravery.

The second important trait of Anglo-Saxon literature is Christian ideals. In adapting to Christianity, the Anglo-Saxons also fit their literary heroes to the new religion. Images of the cross become popular in poems, as well as the idea of Heaven and Hell. Forgiveness is another featured Christian virtue. The heroes desired war and glory, but they fought for Christian principles.

In Anglo-Saxon culture and literature, to be a hero was to be a warrior. A hero had to be strong, intelligent, and courageous. Warriors had to be willing to face any odds, and fight to the death for their glory and people. The Anglo-Saxon hero was able to be all of these and still be humble and kind. In literature Beowulf is, perhaps, the perfect example of an Anglo-Saxon hero.

In Beowulf, the Anglo-Saxon hero is well defined by the actions of Beowulf. It is obvious that Beowulf is the quintessential hero. His strength and courage are unparalleled, and he is much more humble (and honorable) than many of the corrupt warriors around him. Beowulf displays his great strength time after time. Whether he is fighting sea monsters, Grendel's mother, or a horrible firebreathing dragon. By understanding the qualities that make Beowulf a hero, you can then better understand how other Anglo-Saxon epic heroes, such as Fadlan of "The 13th Warrior" or even the warrior Christ in "The Dream of the Rood" fit into their respective worlds. 
First and foremost, an epic hero must look the part. Greek heroes, like Hercules, were not merely mortals, but demigods, and the idea that a hero must be more than a man carries over into AngloSaxon epic poetry. Beowulf is greeted by the first Dane who sees him with an acknowledgment of his awesome presence: "I have never seen a mightier warrior on earth than is one of you, a man in battledress.

"Nor have I ever seen,/ Out of all the men on earth, one greater/ Than has come with you; no commoner carries/ Such weapons, unless his appearance, and his beauty,/ Are both lies." (244-251)

Strength and physical appearance is important, it is no empty gesture; superhuman strength is also essential to the Anglo-Saxon epic hero. In the seventh section, lines 8 to 10 of Beowulf, titled "Hrothgar and Beowulf," Hrothgar describes Beowulf as having the strength of thirty men.

"Who valuable gift-gems of the Geatmen carried / As peace-offering thither, that he thirty men's grapple / Has in his hand, the hero-in-battle.

Courage, in the Anglo-Saxon tradition, works in conjunction with strength, despite the separation that exists in modern culture which sometimes commends restraint and tactical retreats. According to Christopher Garcia of Pace University, Beowulf and other epic heroes are capable of successfully challenging fate -- "which was thought to be unchangeable" -- because of adequate courage. Beowulf himself speaks to this importance of courage when arguing with Unferth. He says, "'Fate often saves an undoomed man when his courage is good."

"Often, for undaunted courage,

fate spares the man it has not already marked." (572-573)

This quotation shows the importance of courage in the Anglo-Saxon culture. Fate, which was thought to be unchangeable, seems to bend for a hero who has enough courage. Beowulf tells Hrothgar and the Danes that he will kill Grendel (which would on its own be a great feat of strength), but he says he will do this without his sword, and this shows his courage and honor. Beowulf then speaks inspiringly to the thanes in the mead-hall.

"But the truth/ Is simple: no man swims in the sea/ As I can, no strength is a match for mine:" lines 533-534

"The fact is, Unferth, if you were truly

as keen and courageous as you claim to be

Grendel would never have got away with

such unchecked atrocity, attacks on your king,

havoc in Heorot and horrors everywhere." (590-594)

When Beowulf speaks these words, he shows his great courage, and displays the proper attitude of the Anglo-Saxon warrior. Death for a warrior is honorable, and courage must be shown through deeds, even if it means death. A hero must be willing to die to achieve glory. He must display courage in the face of overwhelming or impossible odds, and he must have the strength to back his courage.

Appearance, strength and courage -- for the Anglo-Saxon epic hero -- are balanced by humility. After he has defeated both Grendel and Grendel's mother, Beowulf turns down the Danish throne, and decides to return home without treasure. He is described in the poem as "The mildest of men and the gentlest, kindest to his people, and most eager for fame." It should be noted by his eagerness for fame, however, that pride, and possibly hubris, exist in Beowulf simultaneously as his humility, and may be interpreted as a tragic flaw for his ultimate downfall.

In addition to the other qualities possessed by one such as Beowulf, the Anglo-Saxon hero must appear impervious to emotional sorrow or weakness. Anglo-Saxon hero "had to be strong, brave, intelligent, and humble, but he must at all times keep his sorrows and fears to himself." As a warrior the hero must appear stoic and fearless at all times, no matter what. Beowulf is the perfect example of an Anglo-Saxon hero.

The strongest link between Beowulf's flawed heroism and that of a prideful Greek warrior comes after the Scandinavian wanderer's death. Like an ancient champion carried to an honorable funeral, Beowulf is likewise enthroned in glory as his men bury him in "a mound on the headland ... [they] 
extolled his heroic nature and ... gave thanks for his greatness." Thus a flawed hero is glorified, his heroism redeemed by the Anglo-Saxon reverence for death.

Beowulf got ready,

donned his war-gear, indifferent to death (1441-1442)

"You are the last of us, the only one left

of the Waegmundings. Fate swept us away,

sent my whole brave high-born clan

to their final doom. Now I must follow them."

That was the warrior's last word.

He had no more to confide. The furious heat

of the pyre would assail him. His soul fled from his breast

to its destined place among the steadfast ones. (2813-2820)

The hero in Anglo-Saxon culture and literature is best defined as an honorable warrior. The AngloSaxon hero possessed many traits which heroes today possess. They were strong, intelligent, tactful, courageous, and willing to sacrifice all for glory and their people. The heroic traits of the literary characters in Beowulf, define and set the standard for the Anglo-Saxon hero

\section{Websites Visited:}

Beowulfhttps://en.wikipedia.org/wiki/Beowulf

Beowulf (in Old English), Fordhahttp://legacy.fordham.edu/halsall/basis/beowulf-oe.asp

Beowulf quotes http://www.shmoop.com/beowulf/quotes.htm

\section{AUTHORS' BIOGRAPHY}

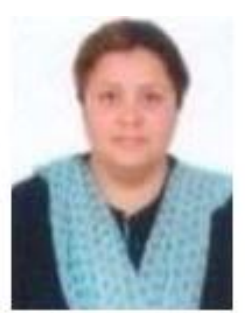

Dr. Anupama Dogra (Ex.Asst.Prof), Army Institute of Higher Education, Pathankot.

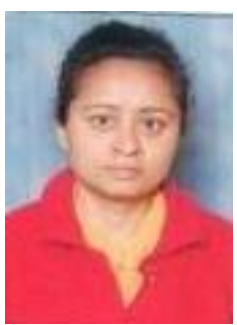

Alka Dogra (Asst. Prof), Sri Sai College of Education, Badhani 